\title{
Effect of Feeding Tannin Rich Oak (Quercus leucotrichophora) Leaves on Immunological Parameters, Antioxidant Status and Microbial Nitrogen Supply of Parasitic Infected Goats in Kumaon Hills
}

\author{
A. Chaurasiya ${ }^{1}$, P. Tamboli ${ }^{*}$, P. Chaurasiya ${ }^{3}$, A. Nehra ${ }^{1}$, B. Sahoo ${ }^{1}$, \\ A. Kuriyal ${ }^{1}$ and M. Sankar ${ }^{1}$ \\ ${ }^{1}$ ICAR-Indian Veterinary Research Institute, Mukteswar, Nainital, Uttarakhand 263138, India \\ ${ }^{2}$ ICAR-National Dairy Research Institute, Karnal, Haryana 132001, India \\ ${ }^{3}$ Nanaji Deshmukh Veterinary Science University, Jabalpur, M.P. 482001, India \\ *Corresponding author
}

\begin{tabular}{l} 
K e y w o r d s \\
$\begin{array}{l}\text { Antioxidant, Condensed } \\
\text { tannin, Immunoglobulin, } \\
\text { Microbial protein and oak } \\
\text { leaves }\end{array}$ \\
Article Info \\
$\begin{array}{l}\text { Accepted: } \\
\text { 04 September } 2018 \\
\text { Available Online: } \\
\text { 10 October } 2018\end{array}$ \\
\hline
\end{tabular}

\section{A B S T R A C T}

The present study was undertaken to explore the immunological, antioxidant effect as well as microbial protein synthesis potency of oak leaves (Quercus leucotricophora) having $3.35 \%$ condensed tannin with its anthelmintic property. Twenty four local male goats of about 6-7 months of age were randomly divided into three homogenous groups $\left(\mathrm{T}_{1}, \mathrm{~T}_{2}\right.$ and $\mathrm{T}_{3}$ ) of eight animals each. Further, each group was subdivided in to 2 sub-groups of 4 animals each and one sub group in each group was treated with synthetic anthelmintic

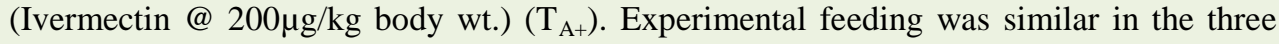
groups except for the roughage source, which was local green grass (Pennisetum clandestinum) in $\mathrm{T}_{1 \mathrm{~A}-}$ and $\mathrm{T}_{1 \mathrm{~A}+}$, oak leaves $\left(Q\right.$. leucotricophora) in $\mathrm{T}_{2 \mathrm{~A} \text { - }}$ and $\mathrm{T}_{2 \mathrm{~A}+}$ and oak leaves supplemented with $\mathrm{PEG}$ in group $\mathrm{T}_{3 \mathrm{~A}-}$ and $\mathrm{T}_{3 \mathrm{~A}+}$, respectively. Microbial nitrogen $\left(\mathrm{gd}^{-1}\right)$ was higher $(\mathrm{P}<0.01)$ in oak fed groups $\left(\mathrm{T}_{2 \mathrm{~A}-}, \mathrm{T}_{2 \mathrm{~A}+}\right)$ than $\mathrm{PEG}$ supplemented groups $\left(\mathrm{T}_{3 \mathrm{~A}-}, \mathrm{T}_{3 \mathrm{~A}+}\right)$ and grass fed groups $\left(\mathrm{T}_{1 \mathrm{~A}-}, \mathrm{T}_{1 \mathrm{~A}+}\right)$. The $\mathrm{IgG}$ and $\mathrm{IgA}$ were decreased at $28^{\text {th }}$ day $\mathrm{PI}$ and again improved significantly in groups treated with anthelmintic and group fed with oak leaves $\left(\mathrm{T}_{1 \mathrm{~A}+}, \mathrm{T}_{2 \mathrm{~A}-}, \mathrm{T}_{2 \mathrm{~A}+}, \mathrm{T}_{3 \mathrm{~A}+}\right)$ while it decreased with PEG supplementation $\left(\mathrm{T}_{3 \mathrm{~A}-}\right)$ and lowest in the non-treated grass fed group $\left(\mathrm{T}_{1 \mathrm{~A}-}\right)$. The antioxidant property from GSH, SOD and catalase was significantly increased in oak fed groups $\left(\mathrm{T}_{1 \mathrm{~A}+}, \mathrm{T}_{2 \mathrm{~A}-}, \mathrm{T}_{2 \mathrm{~A}+}, \mathrm{T}_{3 \mathrm{~A}+}\right)$ than grass fed groups $\left(\mathrm{T}_{1 \mathrm{~A}-}, \mathrm{T}_{1 \mathrm{~A}+}\right)$. It was concluded that feeding of oak leaves having $\mathrm{CT}$ upto $1.6 \%$ in diet improved the microbial nitrogen supply, immunoglobulin status and antioxidant status of growing kids.

\section{Introduction}

Livestock rearing is an integral part of hill farmer's nutrition and economy. Goat is the popular species among marginal, sub-marginal and landless farmers in Himalayan region which is universally accepted as a profitable animal without any threat to ecology. However, animal productivity is quite low mainly due to nutritional inadequacy pertaining to one of the principle cause, i.e. scarcity of forage. The availability of pasture in hilly region is limited to a very short period of the year in rainy season (July to October) 
only which witness the prevalence of highest parasitism in grazing animals (Gupta et al., 1987). Other than fodder scarcity, goats also suffer from heavy gastrointestinal parasitic infection in temperate hills of Himalaya (Kumar et al., 2015), a major problem which adversely affects their health and performance. Worldwide, gastrointestinal nematode, mostly Haemonchus contortus infection (95-97\%) remain a major threat for the economic viability of small ruminants (Hostea et al., 2012). Several studies in the small ruminant species have shown that the consumption of a condensed tannin (CT) rich feed was associated with a modulation of the biology of adult worm populations, affecting particularly the egg excretion (Shaik et al., 2006) through direct and indirect effect. Tannin also has some antioxidant property (Andrade et al., 2005) which hampers parasitic growth. Oak leave (Quercus leucotrichophora) is the dominant, climax tree species and most abundantly available throughout the year in the moist temperate forests of the Indian Himalayan region (Singh et al., 1996) and forms the bulk of livestock feed during the critical forage scarcity period of winters. feeding of oak leaves (3.35\% CT) improves the feed intake and growth performance of goats (Chaurasiya et al., 2018b) with improved the haematological parameters, blood glucose, serum proteins and maintains the BUN as well as liver enzymes level in the body (Chaurasiya et al., 2018a). According to Chaurasiya et al., 2018c Quercus leucotrichophora $(3.35 \%$ CT) leaves also having anthelmintic property without any adverse effect. It also improves the humoralcell mediated immune response with antioxidant property in small ruminants (Pathak et al., 2014) which provide potency to counteract with parasitic infection. Condensed tannin binding agent polyethylene glycol (PEG) has ability to neutralize CT by displacing protein-tannin complexes, as a consequence of CT interact more strongly with PEG than they do with protein. PEG has been used to reduce the negative effect of tannins in livestock which facilitate microbial protein synthesis in vivo (Landau et al., 2000). Keeping in view, the present study was designed to explore the immunological, antioxidant effect as well as microbial protein synthesis potency of feeding $Q$. leucotrichophora leaves as an alternative to control $H$. contortus with or without polyethylene glycol (PEG) in goats infected with $H$. contortus for its anthelmintic property.

\section{Materials and Methods}

The in vivo experiment was carried out at experimental goat farm of Indian Veterinary Research Institute, Mukteshwar in Uttarakhand (28 $8^{\circ} 53^{\prime} 24^{\prime \prime}-31^{\circ} 27^{\prime} 50^{\prime \prime} \mathrm{N}$ and $77^{\circ} 34^{\prime} 27^{\prime \prime}-81^{\circ} 02$ ' $\left.22^{\prime \prime} \mathrm{E}\right)$ of India. It is located at 2250-2350 $\mathrm{m}$ above sea level in the Kumaon regions of temperate Sub Himalayas. The ambient temperature ranges from $-10.0^{\circ} \mathrm{C}$ to $26^{\circ} \mathrm{C}$ and the relative humidity ranges from 43 to $86 \%(150-200 \mathrm{~cm}$ precipitation per annum).

\section{Animals: Selection and grouping}

Twenty four local adult male goats of about 67 months of age were selected at goat farm, Surmane and randomly divided into three homogenous groups $\left(\mathrm{T}_{1}, \mathrm{~T}_{2}\right.$ and $\left.\mathrm{T}_{3}\right)$ of eight animals each based on age and body weight. Further, each group was subdivided in to 2 sub-groups of 4 animals each and one sub group in each group was provided with synthetic anthelmintics $\left(\mathrm{T}_{\mathrm{A}+}\right)$ to compare its effect with natural anthelmintic property of condensed tannin of oak leaves.

\section{Feeds and feeding}

Experimental feeding was similar in the three groups except for the roughage source, which was local green grass (Pennisetum 
clandestinum) in groups $\mathrm{T}_{1 \mathrm{~A}-}$ and $\mathrm{T}_{1 \mathrm{~A}+}$, tanniferous oak tree leaves (Quercus leucotricophora) (Banjh) in group $\mathrm{T}_{2 \mathrm{~A}}$ - and $\mathrm{T}_{2 \mathrm{~A}+}$ and oak tree leaves (Quercus leucotricophora) (Banjh) supplemented with PEG in group $\mathrm{T}_{3 \mathrm{~A}-}$ and $\mathrm{T}_{3 \mathrm{~A}+}$, respectively. The concentrate mixture was fed twice a day, morning and evening. The oak leaves were procured daily and fed to the animals in $\mathrm{T}_{2 \mathrm{~A}-\text {, }}$ $\mathrm{T}_{2 \mathrm{~A}+}, \mathrm{T}_{3 \mathrm{~A}-}$ and $\mathrm{T}_{3 \mathrm{~A}+}$, local grass was fed to $\mathrm{T}_{1 \mathrm{~A}-}$ and $\mathrm{T}_{1 \mathrm{~A}+}$ preferably in the afternoon so as to allow sufficient time for the consumption of concentrate mixture. The PEG was given with the concentrate mixture after dissolving in clean water. Fresh water was offered ad libitum twice daily to all the animals.

\section{Collection of blood}

Blood from all animals was collected at fortnightly intervals of experimental period to study the hematological, serum biochemical, enzymatic profile, immunological parameter and antioxidant property by puncturing the jugular vein with the help of a clean sterilized needle into two separate test tubes. The first test tube contained sodium EDTA and second one was without anticoagulant. The serum was separated carefully from the second test tube to check haemolysis and serum samples were stored at $-20^{\circ} \mathrm{C}$ for further analysis.

\section{Collection and aliquoting of urine}

Urine excreted daily by individual animal was collected separately in urine bottle for $24 \mathrm{~h}$ and were measured with the help of measuring cylinder, then representative sample was brought to the laboratory in properly marked, well stoppered sample bottle.

\section{Analysis of feed and fodder}

The ground samples of feed and feces were analyzed for different proximate constituents as per the methods described by AOAC
(2000). Samples of feeds and faeces were analyzed for different fiber components as per the method given by Van Soest et al., (1991). The extraction and estimation of total phenolics and tannins were done as per the methods of Makkar (2000).

Analysis of urine samples for purine derivatives and microbial protein synthesis

Allantoin in urine and plasma was determined by the colorimetric method of Young and Conway. Urine was analysed directly after filtration $(0.22 \mu \mathrm{m}$ Millipore filter $)$ and dilution (1:50). Uric acid was determined by the colorimetric method. In enzymatic method xanthine and hypoxanthine are converted to uric acid and thus determined as uric acid, which is monitored by its absorbance at 293 nm.

\section{Total PD in urine}

Total $\mathrm{PD}=$ Allantoin $(\mathrm{mmol} / \mathrm{d})+$ Uric acid $(\mathrm{mmol} / \mathrm{d})+$ Xanthine and Hypoxanthine $(\mathrm{mmol} / \mathrm{d})$

\section{Daily purine absorption}

$\mathrm{X}=\mathrm{Y}-\left(0.217 \mathrm{kgW}^{0.75} \mathrm{e}^{-0.25 \mathrm{x}}\right) / 0.84$

Where, $\mathrm{Y}$ is urinary PD excretion and W0.75 represents metabolic body weight $(\mathrm{kg})$ of the animal.

\section{Microbial nitrogen supply}

Microbial nitrogen $(\mathrm{g} /$ day $)=0.727 \mathrm{X}$ (where $\mathrm{X}$ is daily purine absorption)

DOMR: organic matter fermented in rumen

DOMR $=$ Feed intake $\times$ DM content $(\% / 100)$ $\times \mathrm{OM}$ content $(\% / 100) \times \mathrm{OM}$ digestibility $(\% / 100) \times 0.65$ 


\section{Immunological parameters}

Bluegene Goat Immunoglobulin A ELISA kit was used in this study for quantitative estimation of IgA using serum. Goat Immunoglobulin G ELISA kit (Bethyl Laboratories, USA) was used in this study for quantitative estimation of $\mathrm{IgG}$ using serum as sample.

\section{Antixodant profile}

On each collection, Blood samples were collected aseptically from jugular vein of kids in $2 \mathrm{ml}$ appendrop tube with acid citrate dextrose (@1.5ml/10 ml blood) as anticoagulant and centrifuges at $2000 \mathrm{rpm}$ for $15 \mathrm{~min}$ at $4^{0} \mathrm{C}$, followed by separation of plasma and buffy coat. The resulting erythrocyte pellet was washed thrice with 250 $\mathrm{mOsm} / \mathrm{L}$ (pH-7.4) phosphate buffer saline as per Yagi et al., (1989). The erythrocyte pellet (packed RBC) obtained was mixed with an equal volume of PBS to form RBC suspension. $0.5 \mathrm{ml}$ RBC suspension was mixed with $4.5 \mathrm{ml}$ stabilizing solution (EDTA, $2.7 \mathrm{mM}$ and $0.7 \mathrm{mM}, \beta$ marcaptoethanol) to prepare a haemolysate of 1:20 dilution. The haemoglobin in RBC suspension was estimated by Cyanomethaemoglobin method. Reduced glutathione was estimated by DNTB method of Prins and Loos (1969). Catalaes was assayed in erythrocytes by spectrophotometric method as described by Bergmeyer (1983). Superoxide dismutase (SOD) activity of RBC haemolysate samples was measured using nitro blue tetrazolium as a substrate after suitable dilution according to method of Marklund (1974).

\section{Statistical analysis}

All the data generated in the above experiments were statistically analyzed using SPSS (2005) computer package. For comparison of groups, Generalized Linear
Model ANOVA procedure and Duncan's multiple range tests were used (Snedecor and Cochran, 1994).

\section{Results and Discussion}

\section{Chemical composition of experimental diets}

The chemical composition of concentrate mixture, oak leaves (Quercus leucotricophora) and native grass (Pennisetum clandestinum) offered to goats (kids) was within the normal range (Ranjhan, 1998; Paswan et al., 2008) (Table 1). Higher DM intake (DMI) through roughage (oak leaves) raised the total DMI in anthelmintic treated and oak fed groups $\mathrm{T}_{1 \mathrm{~A}+}, \mathrm{T}_{2 \mathrm{~A}-}, \mathrm{T}_{2 \mathrm{~A}+}, \mathrm{T}_{3 \mathrm{~A}-}$ and $\mathrm{T}_{3 \mathrm{~A}+}$ than in grass fed group $\mathrm{T}_{1 \mathrm{~A}-\text {. }}$ The nutritional effects of CT are related with their ability to bind with proteins (dietary and enzymes), structural carbohydrate polymers found in plant cell walls and minerals with an overall effect of depressing the bioavailability of nutrients at specific sites in the gastrointestinal tract (Ndluvo, 2000). Moderate concentration of tannin (2-4.5\% CT) from $L$. corniculatus reduce rumen forage protein degradation due to reversible binding to these proteins and reduce the populations of proteolytic rumen bacteria without reducing the amount of microbial protein synthesis, as a result, there was improvement in milk production, wool growth, ovulation rate and lambing percentage due to action of $\mathrm{CT}$ in increasing EAA absorption from small intestine (Min et al., 2003).

\section{Microbial protein synthesis}

Ruminants' feeds usually have a low purine content, most of which undergoes extensive degradation in the rumen as the result of microbial fermentation. Therefore, nucleic acids leaving the rumen are essentially of microbial origin. Absorbed nucleic acid purine are degraded and excreted in urine as their 
derivatives, allantoin, uric acid, xanthine and hypoxanthine (Chen et al., 1990). The urinary excretion of purine derivatives is directly related to the microbial purine absorption and increasingly being used as well accepted indicator for estimating microbial protein synthesis in the rumen (Fujihara et al., 1987). Daily excretion (mmol/day) of purine derivatives (Allantoin, uric acid, xanthine and hypoxanthine) and total purine, microbial nitrogen supply in urine was significantly increased with CT supplementation as compared to grass fed groups (Table 2).

The DOMI was also significantly increased in oak leaves fed groups than grass fed groups. The DOMI, excretion of purine derivatives and microbial nitrogen supply was significantly decreased with PEG supplementation which might be due to binding of PEG with condensed tannin of oak leaves. In contrast, PEG has been used to reduce the negative effect of tannins in livestock which facilitate microbial protein synthesis in vivo (Landau et al., 2000).

The results are in conformity with the earlier reports that the presence of CT has a potentially beneficial effect to protein nutrition of the host animal by altering partitioning of nutrients towards higher microbial yield rather than short chain fatty acids (Baba et al., 2002). CT supplementation on rumen microbial protein synthesis was similar with the observations found earlier in sheep fed tannin containing Acacia pods and $F$. infectoria (Ngwa et al., 2002). The findings suggested that the feeding of $Q$. leucotrichophora leaves as CT source having positive impact on microbial nitrogen synthesis.

Although tannins are generally regarded as antinutritional, certain tannins at lowmoderate concentrations are known to enhance microbial protein synthesis (Bhatta et al., 2002) and PEG supplementation is not useful with low-moderate level of CT as it decreases the microbial protein synthesis.

\section{Immunological status}

Table 3 showing that, $\operatorname{IgG}$ and $\operatorname{Ig} \mathrm{A}$ were decreased at $28^{\text {th }}$ day of post infection and again improved significantly in anthelmintic treated groups $\left(\mathrm{T}_{1 \mathrm{~A}+}, \mathrm{T}_{2 \mathrm{~A}+}, \mathrm{T}_{3 \mathrm{~A}+}\right)$ and group fed with oak leaves $\left(\mathrm{T}_{2 \mathrm{~A}-}\right)$ while it decreased with PEG supplementation $\left(\mathrm{T}_{3 \mathrm{~A}-}\right)$ and lowest in the non-treated grass fed group $\left(\mathrm{T}_{1 \mathrm{~A}-}\right)$. The grass fed group of animals showed higher concentration of $\mathrm{IgE}$ throughout the experimental trial compared to anthelmintic treated groups. Highest concentration was observed on $14^{\text {th }}$ to $21^{\text {st }}$ day of post infection (PI). After $21^{\text {st }}$ day, concentration showed a continuous decreased up to the end of experimental trial. With conformity of these findings Kooyman et al., (1997) reported increased level of IgE specific to $H$. contortus 2-4 weeks PI. Increased level of $\operatorname{IgG}_{1}$ has been reported to be followed by $\operatorname{IgG}_{2}, \operatorname{IgM}$ and $\operatorname{IgA}$ (Schallig et al., 1994). Among all the immunoglobulin isotypes, $\operatorname{IgE}$ is the most investigated in nematode infections and it has been found to increase the most during infection. In the present experiment, grass fed group of animals showed higher concentration of $\operatorname{IgE}$ throughout the experimental trial compared to anthelmintic treated and oak fed groups.

\section{Antioxidant status}

The antioxidant status is the representative of health status of the body as they are important part of body defense mechanism by scavenging free radicals (ROS: Reactive oxygen species) which damages the biological system (Padh, 1991). Haematological values of GSH, SOD and catalase are the representative of antioxidant status of body (Bisla et al., 2002; Han et al., 2004). 
Table.1 Chemical composition (\% DM basis) of different feeds and fodders

\begin{tabular}{|c|c|c|c|}
\hline Nutrients & Concentrate mixture & Pennisetum clandestinum & Quercus leucotrichophora \\
\hline Organic matter & 92.23 & 91.62 & 96.45 \\
\hline Crude protein & 21.74 & 9.84 & 10.61 \\
\hline Ether extract & 4.41 & 1.50 & 5.01 \\
\hline Total carbohydrates & 66.08 & 80.28 & 80.82 \\
\hline Neutral detergent fiber & 36.80 & 76.70 & 62.30 \\
\hline Acid detergent fiber & 14.92 & 47.80 & 52.67 \\
\hline Ash & 7.77 & 8.38 & 3.55 \\
\hline Calcium & 1.22 & 0.67 & 1.21 \\
\hline Phosphorus & 0.72 & 0.42 & 0.19 \\
\hline Total tannin & - & - & 6.45 \\
\hline Condensed tannin & - & - & 3.35 \\
\hline Hydrolysable tannin & - & - & 3.10 \\
\hline
\end{tabular}

Table.2 Effect of feeding tanniferous oak leaves on microbial nitrogen supply

\begin{tabular}{|c|c|c|c|c|c|c|c|c|}
\hline Fortnight & $\mathbf{T}_{1 \mathrm{~A}-}$ & $\mathbf{T}_{1 \mathrm{~A}+}$ & $\mathbf{T}_{2 \mathrm{~A}-}$ & $\mathbf{T}_{2 \mathrm{~A}+}$ & $\mathbf{T}_{3 \mathrm{~A}-}$ & $\mathbf{T}_{3 \mathrm{~A}+}$ & SEM & P value \\
\hline Allantoin ** (mmol/day) & $4.25^{\mathrm{a}}$ & $4.38^{\mathrm{a}}$ & $5.00^{b}$ & $5.00^{b}$ & $4.25^{\mathrm{a}}$ & $4.50^{\mathrm{ab}}$ & 0.09 & 0.01 \\
\hline Uric acid * (mmol/day) & $0.18^{\mathrm{a}}$ & $0.21^{\mathrm{ab}}$ & $0.23^{b}$ & $0.24^{b}$ & $0.17^{\mathrm{a}}$ & $0.20^{\mathrm{ab}}$ & 0.02 & 0.04 \\
\hline $\begin{array}{l}\text { Xanthine and } \\
\text { Hypoxanthine* (mmol/day) }\end{array}$ & $0.25^{\mathrm{a}}$ & $0.31^{\mathrm{ab}}$ & $0.32^{\mathrm{ab}}$ & $0.34^{\mathrm{b}}$ & $0.28^{a b}$ & $0.32^{\mathrm{ab}}$ & 0.02 & 0.02 \\
\hline Total PD* & $4.68^{\mathrm{a}}$ & $4.89^{\mathrm{ab}}$ & $5.55^{b}$ & $5.58^{b}$ & $4.69^{\mathrm{a}}$ & $5.02^{\mathrm{ab}}$ & 0.10 & 0.02 \\
\hline PD absorption (mmol/day) & 5.25 & 5.62 & 6.30 & 6.61 & 5.56 & 5.69 & 0.14 & 0.23 \\
\hline Microbial N*** (g/day) & $3.40^{\mathrm{a}}$ & $3.56^{\mathrm{a}}$ & $4.03^{b}$ & $4.06^{b}$ & $3.41^{\mathrm{a}}$ & $3.65^{\mathrm{a}}$ & 0.07 & 0.01 \\
\hline DOMR & 10.52 & 16.86 & 20.28 & 21.14 & 18.97 & 19.21 & 1.87 & 0.66 \\
\hline DOMI*** & $9.92^{\mathrm{a}}$ & $10.51^{\mathrm{a}}$ & $11.85^{b c}$ & $12.19^{c}$ & $10.25^{\mathrm{a}}$ & $10.71^{\mathrm{ab}}$ & 0.23 & 0.01 \\
\hline
\end{tabular}

a,b,c,ab,bc Means bearing different superscripts in a column differ significantly* $\mathrm{P}<0.05, * * \mathrm{P}<0.01$ 
Table.3 Effect of feeding tanniferous oak leaves on immunoglobulins

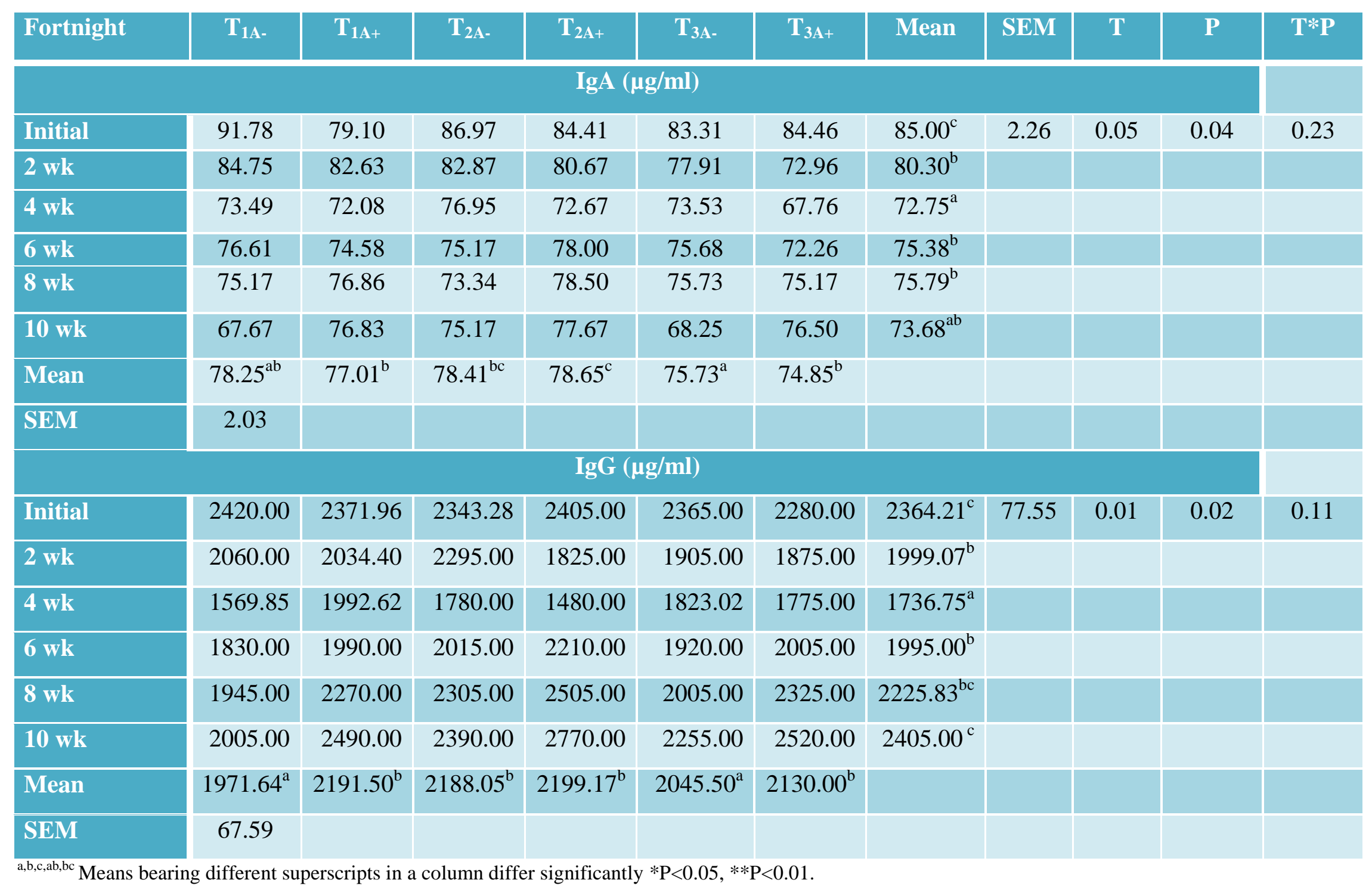


Table.4 Effect of feeding tanniferous oak leaves on antioxidant status

\begin{tabular}{|c|c|c|c|c|c|c|c|c|}
\hline \multirow[t]{2}{*}{ Treatments } & \multicolumn{3}{|c|}{ Days post experimental feeding } & \multirow[t]{2}{*}{ Mean } & \multirow[t]{2}{*}{ SEM } & \multicolumn{2}{|c|}{ P values } & \multirow[b]{2}{*}{$T^{*} \mathrm{P}$} \\
\hline & 0 & 60 & 120 & & & $\mathrm{~T}$ & $\mathrm{P}$ & \\
\hline \multicolumn{9}{|c|}{ GSH ( $\mu \mathrm{mol} / \mathrm{ml}$ haemolysate) } \\
\hline $\mathbf{T}_{1 \mathrm{~A}-}$ & 1.34 & 1.35 & 1.36 & $1.35^{\mathrm{a}}$ & 0.021 & 0.15 & 0.88 & 0.43 \\
\hline $\mathrm{T}_{1 \mathrm{A+}}$ & 1.41 & 1.41 & 1.42 & $1.4^{\mathrm{a}}$ & & & & \\
\hline $\mathrm{T}_{2 \mathrm{~A}-}$ & 1.51 & 1.51 & 1.5 & $1.5^{\mathrm{b}}$ & & & & \\
\hline$T_{2 \mathrm{At}}$ & 1.56 & 1.54 & 1.53 & $1.54^{\mathrm{b}}$ & & & & \\
\hline $\mathrm{T}_{3 \mathrm{~A}-}$ & 1.44 & 1.44 & 1.46 & $1.44^{\mathrm{ab}}$ & & & & \\
\hline $\mathrm{T}_{3 \mathrm{~A}-}$ & 1.49 & 1.49 & 1.48 & $1.49^{\mathrm{ab}}$ & & & & \\
\hline Mean & 1.46 & 1.46 & 1.46 & & & & & \\
\hline SEM & 0.11 & & & & & & & \\
\hline \multicolumn{9}{|c|}{ SOD (mmol MTT formazon formed/g Hb) } \\
\hline$T_{1 A-}$ & 1.55 & 1.49 & 1.51 & $1.52^{\mathrm{a}}$ & 0.02 & 0.01 & 0.29 & 0.64 \\
\hline $\mathbf{T}_{1 \mathrm{A+}}$ & 1.53 & 1.68 & 1.49 & $1.56^{\mathrm{a}}$ & & & & \\
\hline $\mathrm{T}_{2 \mathrm{~A}-}$ & 1.39 & 1.75 & 1.71 & $1.61^{\mathrm{ab}}$ & & & & \\
\hline$T_{2 \mathrm{~A}+}$ & 1.7 & 1.71 & 1.75 & $1.72^{b}$ & & & & \\
\hline$T_{3 A-}$ & 1.7 & 1.7 & 1.74 & $1.71^{\mathrm{b}}$ & & & & \\
\hline $\mathrm{T}_{3 \mathrm{~A}-}$ & 1.7 & 1.71 & 1.7 & $1.70^{\mathrm{b}}$ & & & & \\
\hline Mean & 1.59 & 1.67 & 1.65 & & & & & \\
\hline SEM & 0.23 & & & & & & & \\
\hline \multicolumn{9}{|c|}{ Catalase (mK/L haemolysate) } \\
\hline$T_{1 A-}$ & 1.19 & 1.2 & 1.2 & $1.19^{\mathrm{a}}$ & 0.16 & 0.04 & 0.08 & 0.47 \\
\hline $\mathrm{T}_{1 \mathrm{~A}+}$ & 1.2 & 1.2 & 1.2 & $1.20^{\mathrm{a}}$ & & & & \\
\hline$T_{2 A-}$ & 1.24 & 1.23 & 1.24 & $1.24^{\mathrm{b}}$ & & & & \\
\hline$T_{2 \mathrm{~A}+}$ & 1.25 & 1.25 & 1.27 & $1.26^{\mathrm{b}}$ & & & & \\
\hline $\mathbf{T}_{3 \mathrm{~A}-}$ & 1.21 & 1.22 & 1.26 & $1.23^{\mathrm{b}}$ & & & & \\
\hline $\mathbf{T}_{3 \mathrm{~A}-}$ & 1.25 & 1.24 & 1.27 & $1.25^{\mathrm{b}}$ & & & & \\
\hline Mean & 1.22 & 1.22 & 1.24 & & & & & \\
\hline SEM & 0.17 & & & & & & & \\
\hline
\end{tabular}

Table 4 shows the antioxidant status from GSH and SOD was significantly increased $(\mathrm{P}<0.05)$ in oak leaves fed groups $\left(\mathrm{T}_{1 \mathrm{~A}+}, \mathrm{T}_{2 \mathrm{~A}-}\right.$, $\left.\mathrm{T}_{2 \mathrm{~A}+}, \mathrm{T}_{3 \mathrm{~A}_{+}}\right)$than grass fed groups $\left(\mathrm{T}_{1 \mathrm{~A}-}, \mathrm{T}_{1 \mathrm{~A}+}\right)$ which might be due to anthelmintic property of tannin of oak leaves reducing the worm load and indirectly improved the antioxidant status of animals fed oak leaves. However, the catalase activity in different treatments was similar. The GSH level was not altered with PEG supplementation in oak fed groups $\left(\mathrm{T}_{3 \mathrm{~A}}\right.$-,
$\mathrm{T}_{3 \mathrm{~A}+}$ ), might be due to binding of tannin of oak leaves by PEG. It is assumed that dietary condensed tannins may display their first antioxidant defence in the digestive tract, by limiting ROS formation and scavenging them. Similar to the findings Dubey et al., (2011) reported increased GSH, SOD and catalase activity in kids feeding with 1-2\% CT.

It was concluded that feeding of oak leaves having CT upto $1.6 \%$ in diet improved the 
microbial nitrogen supply, immunoglobulin status and antioxidant status of growing kids without any adverse effect in the animal health and performance.

\section{Acknowledgment}

Special thanks to ICAR-IVRI for providing the necessary facilities and funding for conducting this experiment.

\section{References}

A.O.A.C. 2000. Association of official analytical chemists: Official Methods of Analysis. 16th Edition. Washington, DC.

Andrade, R.G., Dalvi, L.T., Silva, J.M.C., Lopes, G.K.B., Alonso, A. and HermesLima, M. 2005.The antioxidant effect of tannic acid on the in vitro coppermediated formation of free radicals. Arch. Biochem. Biophys. 437: 1-8.

Baba, A.S.H., Castro, F.B. and Orskov, E.R. 2002. Partitioning of energy and degradability of browse plants in-vitro and the implications of blocking effects of tannin by the addition of polyethylene glycol. Anim. Feed Sci. Technol. 76: 77-88.

Bergmeyer, H.U. 1983. UV method of catalase assay. In: Methods of enzymatic analysis. Vol. $3^{\text {rd }}$, Weinheim, Deerfield Beach, Florida, Bansal. p. 273.

Bhatta, R., Shinde, A.K., Vaithiyanathan, S., Sankhyan, S.K. and Verma, D.L. 2002. Effect of polyethylene glycol-6000 on nutrient intake, digestion and growth of kids browsing Prosopis cineraria. Anim. Feed Sci. Technol. 101: 45-54.

Bisla, R.S., Singh, J. and Krishnamurthy, D. 2002. Assessment of oxidative stress in buffaloes suffering from diaphragmatic hernia. Indian J. Vet. Surg. 23: 77-80.
Chaurasiya, A., B. Sahoo, A. Kuriyal, A. Nehra, M. Sankar and Tamboli, P. 2018b. Effect of Feeding Oak (Quercus leucotrichophora) Leaves on Growth and Performance of Goats in Kumaon Hills. Int.J.Curr.Microbiol.App.Sci. 7(07): 1090-1100.

Chaurasiya, A., P. Tamboli, A. Nehra, A. Kuriyal and Uniyal, S. 2018c. Effect of Feeding Oak (Quercus leucotrichophora) Leaves as Alternative Control of Gastro Intestinal Nematode Infection of Goat in Kumaon Hills. Int.J.Curr.Microbiol.App.Sci. $\quad$ 7(07): 1380-1388.

Chaurasiya, A., Tamboli, P., Sahoo, B., Kuriyal, A., Nehra, A. and Sankar, M. 2018a. Effect of feeding oak (Quercus leucotrichophora) leaves on haematological and biochemical parameters of parasitic infected goat in Kumaon hills. Int.J.Agri.Res. 10(12): 6392-6397.

Chen, X.B., Hovell, F.D.DeB., Orskov, E.R. and Brown, D.S. 1990. Excretion of purine derivatives by ruminants: effect of exogenous nucleic acid supply on purine derivative excretion by sheep. British J. Nutr. 63: 131-142.

Dubey, M., Dutta, N., Sharma, K., Pattanaik, A.K., Benerjee, P.S. and Singh, M. 2011. Effect of condensed tannin supplementation through a tree leaves mixture on erythrocytic antioxidant status and gastrointestinal nematodes in kids. Anim. Nutr. Feed Technol. 12: 91102.

Fujihara, T., Orskov, E.R. and Reeds, P.J. 1987. The effect of protein infusion on urinary excretion of purine derivatives in ruminants nourished by intra-gastric nutrition. J. Agric. Sci. Camb. 109: 712.

Gupta, R.P., Yadav, C.L. and Choudhry, S.S. 1987. Epidemiology of gastrointestinal nematodes of sheep and goat in 
Haryana, Indian. Vet. Parasitol. 24:117127.

Han, B., Yoon, S., Su, J., Han, H.R., Wang, M., Qu, W. and Zhong, D. 2004. Effect of selenium, copper and magnesium on antioxidant enzymes and lipid peroxidation in bovine fluorosis. Asian Aust. J. Anim. Sci. 17: 1695-1699.

Hostea, H., Martinez-Ortiz-De-Montellano, C., Manolarakia, F., Bruneta, S., OjedaRobertos, N., Fourquauxd, I., TorresAcostac, J.F.J. and Sandoval-Castroc. C.A. 2012. Direct and indirect effects of bioactive tannin-rich tropical and temperate legumes against nematode infections. Vet. Parasitol. 186: 18-27.

Kooyman, F. N., Van Kooten, P. J., Huntley, J. F., MacKellar, A., Cornelissen, A. W. and Schallig, H. D. 1997. Production of a monoclonal antibody specific for ovine immunoglobulin $\mathrm{E}$ and its application to monitor serum $\operatorname{IgE}$ responses to Haemonchus contortus infection. Parasitol. 114(4): 395-406.

Kumar, A., Sankar, M., Chaurasiya, A., Kuriyal, A., Kumar, R., Ahmed, H., Sahoo, B., Sharma, A. K. and Prasad, A. 2015. Haematobiochemical changes in subclinical experimental infection with Haemonchus contortus in Himalayan hill goats. J.Vet. Parasitol. 29(2): 98-105

Landau, S., Silanikove, N., Nitsan, Z., Barkai, D., Baram, H., Provenza, F.D. and Perevolotsky, A. 2000. Short-term changes in eating patterns explain the effect of condensed tannins on feed intake in heifers. Appl. Anim. Behav. Sci. 69: 199-213.

Makkar, H.P.S. 2000. Quantification of tannins in tree foliage. A laboratory manual for the FAO/IAEA co-ordinated research project on "use of nuclear and related techniques to develop simple tannin assays for predicting and improving the safety and efficiency of feeding ruminants on tanniniferous tree foliage". Joint FAO/IAEA working document, IAEA, Viena. pp. 1-26.

Marklund, S. and Marklund, G. 1974. Involvement of superoxide anion radicles in autoxidation of pyrogallol and convenient assay for superoxide dismutase. Europ. J. Biochem. 47: 469474.

Min, B.R., Barry, T.N., Attwood, G.T. and McNabb, W.C. 2003. The effect of condensed tannins on the nutrition of ruminants fed fresh temperate forages: a review. Anim. Feed Sci. Technol. 106: 3-19.

Molan, A.L., Meagher, L.P., Spencer, P.A. and Sivakumaran S. 2003. Effect of flavan-3-ols in-vitro egg hatch, larval development and viability of infective larvae of Trichostrongylus colubriformis. Int. J. Parasitol. 33: 1691-1698.

Ndluvo, L.R. 2000. Tannins in animal agriculture: friend or foe. In: Proceedings of the South African Society of Animal Science Congress, 25-27 July, pp. 51-52.

Ngwa, A.T., Nsah, I.V. and Iji, P.A. 2002. Effect of supplementing bald hay with a dry meal or silage from pods of Acacia sieberiana with or without wheat bran on voluntary intake, digestibility, excretion of purine derivatives, nitrogen utilization and weight gain in South African Merino sheep. Livest. Prod. Sci. 77: 253-264.

Padh, H. 1991. Vitamin C: Newer insights into the biochemical functions. Nutritional riviews, 49: 65-71.

Paswan, V.K., Mahapatra, R.K., Meena, H.R. and Sahoo, A. 2008. Nutrient composition and phenolic constituents in some feed and fodder samples from temperate regions of Kumaon Himalaya. Trop. Anim. Health Prod. 44(8): 1931-38. 
Pathak, A. K., Dutta, N., Banerjee, P. S., Goswami, T. K. and Sharma, K. 2014. Effect of condensed tannins supplementation through leaf meal mixture on voluntary feed intake, immune response and worm burden in Haemonchus contortus infected sheep. J. Parasitic Diseases. 10: 35-43.

Prins and Loos. 1969. Biochemical methods in red cell genetics. Academic press, pp. 127-129.

Ranjhan, S. K. 1998. Nutrient Requirements of Livestock and Poultry. ICAR Publication, New Delhi.

Schallig, H. D. F. H., Leeuwen, M. A. W. and Hendrikx, W. M. L. 1994. Immune response of Texel sheep to excretory/secretory products of adult Haemonchus contortus. Parasitol. 108: 351-357.

Shaik, S.A., Terrill, T.H., Miller, J.E., Kouakou, B., Kannan, G., Kaplan, R.M., Burke, J.M. and Mosjidis, J.A. 2006. Sericea lespedeza hay as a natural deworming agent against gastrointestinal nematode infections in goats. Vet. Parasitol. 139: 150-157.

Singh, P., Biswas, J.C., Somvanshi, R., Verma, A.K., Deb, S.M. and Dey, R.A. 1996. Performance of pashmina goats fed on oak (Quercus semecarpifolia) leaves. Small Rumin. Res. 22: 123-130.

Snedecor, G.W and Cochran, W.G. 1989. Statistical Methods, 8th Ed., Iowa State Press, Iowa City, USA.

SPSS (2005). SPSS Base applications Guide Version 20. Chicago, II, USA.

Van Soest, P.J., Robertson, J.B. and Lewis, B.A. 1991. Methods for dietary fiber, neutral detergent fiber, and nonstarch polysaccharides in relation to animal nutrition. J. Dairy Sci. 74: 3583-3587.

Yagi, Y., Furunchi, S., Takashi, H. and Koyama, H. 1989. Abnormality of osmotic fragility and morphological disorder of bovine erythrocytes infected with Theileria sargonti. Japanese J. Vet. Sci. 51: 389-395.

\section{How to cite this article:}

Chaurasiya, A., P. Tamboli, P. Chaurasiya, A. Nehra, B. Sahoo, A. Kuriyal and Sankar, M. 2018. Effect of Feeding Tannin Rich Oak (Quercus leucotrichophora) Leaves on Immunological Parameters, Antioxidant Status and Microbial Nitrogen Supply of Parasitic Infected Goats in Kumaon Hills. Int.J.Curr.Microbiol.App.Sci. 7(10): 455-465. doi: https://doi.org/10.20546/ijcmas.2018.710.049 